\title{
The Effects of Self-Efficacy on Motivation of Reading English Academic Text
}

\author{
Fuad Hasyim \\ Department of Management, Faculty of Economics, Universitas Islam Indonesia
}

\begin{abstract}
The motivation of reading the academic text, especially in the English language, has been a problem for students of higher education. Whereas, reading ability is one of the important factors of students' successful learning. This research aims to analyze the role of student's self-efficacy in the level of motivation to read the textbooks in the English Language. This research applied quantitative approach. The population of this research is the whole students majoring in Management, Faculty of Economics, Universitas Islam Indonesia, that take Basic Academic Reading course in the first semester. The research's primary data was collected by closed questionnaire, and supported by structured interviews (by 90\% response rate). Meanwhile, the sampling technique used is purposive random sampling, and data analysis method used is Pearson Product Moment's correlative coefficient. The result of this research revealed that students' Self-Efficacy (SE) has a significant positive influence on their Motivation in Interest Aspect (MI), Motivation in Dedication Aspect (MD), and Motivation in Self-confidence Aspect (MC).
\end{abstract}

Keywords: motivation in confidence aspect, motivation in dedication aspect, motivation in interest aspect, self-efficacy

\section{INTRODUCTION}

English reading skill needs the complex challenges, which are related to each other, such as attention, memory, language, and motivation. Therefore, every student who could read well, it means he/she has owned the important basic understanding related to writing the alphabet (Snow, Burns, \& Griffin, 1998). So that, without sufficient basic skill, students will not be able to absorb the essence of assigned reading materials.

Basically, one's language ability will be supported by two side factors; both are skill and will. 'Skill' aspect includes vocabularies, comprehension, phonemes, etc while 'will' aspect includes motivation to reading. Motivation is the most important part of reading (Cambria \& Guthrie, 2010). According to Snow et al. (1998), motivation is one of the factors that determine the level of one's reading skill. Therefore, the success of teaching reading depends on reading motivation for various intention.

Further more, Snow et al. (1998) named three difficulties that may frustrate every student of reading skill class; first, the difficulty to understand and use the basic alphabet. Second, failure to master spoken language skill for reading, and to get a new strategy that is surely needed for reading. Third, lack of early motivation to reading or failure to develop appreciative awareness as a reward to the reading process. Hence, English language teachers, especially reading class, must find the best way to push their student to read, so they enjoy reading as a fun activity. As a good premier motivation, a teacher should show to the students the importance of being able to read well.

Recently, English learning is still considered as a burden and a fright by most of the Indonesian students. In other hand, students have experienced the various unpleasant moment when joining the process of English class (Kevin, 2018). This negative outlook toward English study has a serious negative impact on motivation to learn the English language.

The term of self-efficacy refers to one's view of self-ability to accomplish a certain task. This view could influence the choice of personal activity, effort, perseverance, and achievement. Every student is usually involved in a certain activity with the different level of self-efficacy, this difference is influenced by person's previous experience, personal qualities, and his or her social support (Schunk, 2003). It means, students with strong efficacy to learn English may have a high motivation for completing each task. 
Therefore, it is very important to help students who are working to improve their belief that they are able to do the reading tasks well. This is if they try to learn and apply what they have learned. Self-efficacy is an important factor in developing motivation, the factor that makes a person to be involved and devote physical and mental strength in a certain activity. Therefore, to help students become highly motivated readers, teachers must work hard to change the student's paradigm, from "can not" to read an English textbook to be "can".

This research examined the influence of self-efficacy on student's motivation in learning English, especially reading material of English textbook in the Department of Management, Faculty of Economics Universitas Islam Indonesia. Margolis \& McCabe (2003) have examined the importance of self-efficacy in learners' motivation which has a significant impact on the high motivation of learning, so that, it will improve their achievement. Margolis \& McCabe (2003) describe that self-efficacy often grows by the influence of family, school, and community. Therefore, it is very important to foster the right belief in their ability to learn. Research on the effects of self-efficacy and learning motivation has been widely accomplished. Unfortenetely, linking self-efficacy with reading motivation is very rarely studied, especially when it is associated with reading an English textbook.

Bandura (1997) defines self-efficacy as an affirmative answer to the question "Can I do this task?" If students can respond positively, then they can show better performance and be motivated to choose more challenging tasks. Therefore, students may exhibit a high self-efficacy attitude while others do not. Students with low self-efficacy tend to be unenthusiastic to read. Thus, students will exploit strong effort and spirit in their favorite activities and on other activities that they believe can work on (Karen D. Wood, Anne Tope Edwards, \& Patricia Hill-Miller, 2006).

According to Bandura (1997), self-efficacy is a positive attitude when accepting a task. That attitude is based on the belief in the ability to do every task addressed to him. Bandura said this attitude will have an impact on the selection of activities, effort, perseverance, and achievement. Margolis \& McCabe (2003) explain that self-efficacy is the personal belief about their ability to succeed in certain tasks. Thus, Self-efficacy refers to the individual view of self-ability in completing tasks. Meanwhile, each individual has a different level of self-efficacy. This is due to factors of prior experience, personal quality, and social support (Schunk, 2003).

Cambria \& Guthrie (2010) paralleled the meaning of motivation with values, beliefs, and behaviors that surround someone activities. Productive values and beliefs will cap in excitement, while other values will lead to hard work. McCabe (2003) concluded that self-efficacy has an important role to the level of someone motivation, explicitly in the level of engagement and the expression of physical and mental energy.

In the context of the reading activity, Cambria \& Guthrie (2010) named three aspects of motivation that encourage someone to read intensively. A learner may have all that three aspects or may just one. The three motivations are (1) interest, (2) dedication, and (3) confidence. Therefore, an interested learner will read by enjoying it, a dedicated learner will read because he/she believes that it is important, and a confident learner will read because he/she believes that he/she can do it.

Based on the study of the theory, it can be hypothesized:

H1. There is a significant positive influence of self-efficacy on the motivation of reading English text in the interest aspect.

H2. There is a significant positive influence of self-efficacy on the motivation of reading English text in the aspect of dedication.

H3. There is a significant positive influence of self-efficacy on the motivation of reading English text in the aspect of self-confidence. 
This research model can be described in the following figure:

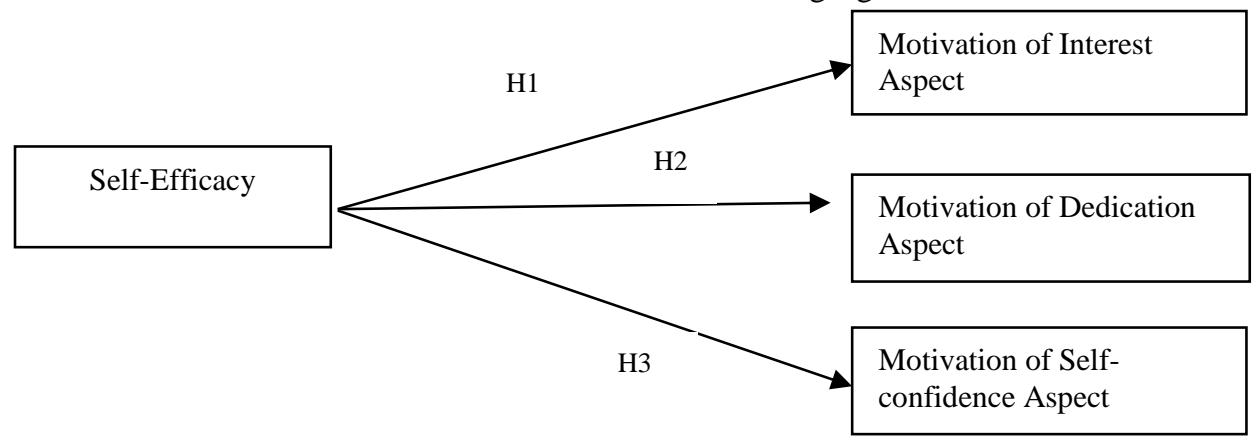

Figure 1. Research Model

\section{RESEARCH METHOD}

The purpose of this research is to analyze the causality relation between the level of self-efficacy to the level of students' motivation on reading English textbooks. This research used quantitative approach. The primary data collection was done by giving a set of questions through questionnaires to the respondents. So that, the research got a picture of students' self-efficacy and reading motivation. The population, at the same time, the respondents in this research are the students who were taking the Basic Academic Reading class at the Department of Management, Faculty of Economics, Universitas Islam Indonesia. The target sample in this research is 131 students. However, the number of respondents who answered correctly totaled up to 100 respondents. The questionnaires have been distributed with random sampling technique. In addition, the writer has conducted literature review extensively by examining concepts that are closely related to self-efficacy and reading motivation. To facilitate the observation, respondents were limited to three classes where the researcher has been teaching Basic Basic Reading class.

Correlation analysis and regression analysis was used in this study. Correlation analysis was used to examine the relationship between two variables, to know the degree of relationship between variable $\mathrm{X}$ (self-efficacy) to variable Y (motivation to read English text). This research used Pearson product moment correlation technique. While regression analysis is intended to determine the form of the relationship of variable $\mathrm{Y}$ to the value of variable $\mathrm{X}$.

\section{RESULTS AND DISCUSSION}

\subsection{Characteristic Description and Respondences' Profile}

Based on table 1, it can be revealed that the respondents, in sequence, have durations of daily reading at least 1-3 hours a day with a total of $46 \%$; less than 1 hour $40 \%$; and more than 3 hours $13 \%$. For the experience in several English courses, most respondents have attended a grammar course of 32\%; conversation 20\%; TOEFL 18\%; never 16\%; and others $14 \%$. Meanwhile, most of the respondents have taken English courses for 1-3 months 32\%, having fiction as the favorite reading material of 52\%, and 69\% of respondent are male. 
Tabel 1. Characteristic of Respondents

\begin{tabular}{|c|c|c|c|}
\hline Respondent & Characteristics & Frequency & Percent \\
\hline \multirow{2}{*}{ Gender } & Male & 61 & 61 \\
\hline & Female & 39 & 39 \\
\hline \multirow{3}{*}{ Duration of Reading } & $<1$ Hour & 41 & 41 \\
\hline & 1-3 Hours & 46 & 46 \\
\hline & $>3$ Hours & 13 & 13 \\
\hline \multirow{5}{*}{ Type of Courses } & Never & 16 & 16 \\
\hline & Grammar & 32 & 32 \\
\hline & Conversation & 20 & 20 \\
\hline & TOEFL & 18 & 18 \\
\hline & Others & 14 & 14 \\
\hline \multirow{6}{*}{$\begin{array}{l}\text { Motivation of Joining } \\
\text { the Course }\end{array}$} & Never & 1 & 1 \\
\hline & $\begin{array}{l}\text { School Exam's } \\
\text { Condition }\end{array}$ & 29 & 29 \\
\hline & Blind Follow & 22 & 22 \\
\hline & Obligation & 14 & 14 \\
\hline & Others & 34 & 34 \\
\hline & Total & 100 & 100 \\
\hline \multirow{4}{*}{ Duration fo Reading } & Never & 13 & 13 \\
\hline & $<1$ Month & 28 & 28 \\
\hline & 1-3 Months & 33 & 33 \\
\hline & $>3$ Month & 26 & 26 \\
\hline \multirow{5}{*}{ Favorite Books } & Never & 1 & 1 \\
\hline & Fiction & 52 & 52 \\
\hline & Non-Fiction & 32 & 32 \\
\hline & Others & 15 & 15 \\
\hline & Total & 100 & 100 \\
\hline
\end{tabular}

Processed Primary Data, 2017

The following data indicate that respondents generally have moderate self-efficacy. Furthermore, the data show that the respondents' motivation on reading English textbooks in the interest aspect is at the average of 3.39 with a standard deviation of 0.777714 . Thus, in this variable $(\mathrm{X})$, respondents are at a pretty good level. In sequence, the average level of motivation in the aspect of dedication and confidence is at an average of 3.89 with a standard deviation of 0.77714 ; and 3.39 with a standard deviation of 0.77714 . Thus, respondents generally have a pretty good level of quality in perceiving each variable.

Tabel 2. Descriptive Statistic of Study Variables

\begin{tabular}{lccccc}
\hline & $\mathrm{N}$ & Minimum & Maximum & Mean & Std. Deviation \\
\hline Self-Efficacy & 100 & 2,00 & 5,00 & 3,8200 &, 62571 \\
Interest & 100 & 1,00 & 5,00 & 3,3900 &, 77714 \\
Dedication & 100 & 1,00 & 5,00 & 3,8900 &, 77714 \\
Confidence & 100 & 2,00 & 5,00 & 3,3900 &, 72328 \\
Valid N & 100 & & & & \\
(listwise) & & & & & \\
\hline
\end{tabular}

Source: Processed Data, 2017

In addition, the correlation of all research variables is shown in the following table. The results show the significance level below 0.05 , it means that each research variable has a positive and significant relationship. 
Tabel 3. Correlation of study Variables

\begin{tabular}{|c|c|c|c|c|}
\hline & $\begin{array}{c}\text { X } \\
\text { (Self-Efficacy) }\end{array}$ & $\begin{array}{c}\mathrm{Y} 1 \\
\text { (Interest) }\end{array}$ & $\begin{array}{c}\text { Y2 } \\
\text { (Dedication) }\end{array}$ & $\begin{array}{c}\text { Y3 } \\
\text { (Confidence) } \\
\end{array}$ \\
\hline \multirow{2}{*}{ X (Self- Efficacy) } & 1 &, $390^{* *}$ &, $509^{* *}$ &, $440^{* *}$ \\
\hline & &, 000 &, 000 &, 000 \\
\hline \multirow{2}{*}{ Y1 (Interest) } &, $390^{* *}$ & 1 &, $581^{* *}$ & $676^{* *}$ \\
\hline &, 000 & & ,000 &, 000 \\
\hline \multirow{2}{*}{ Y2 (Dedication) } &, $509^{* *}$ &, $581^{* *}$ & 1 &, $304^{* *}$ \\
\hline & ,000 & ,000 & &, 002 \\
\hline \multirow{2}{*}{ Y3 (Confidence) } &, $440^{* *}$ &, $676^{* *}$ &, $304^{* *}$ & 1 \\
\hline & 000 & 000 &, 002 & \\
\hline
\end{tabular}

\subsection{Validity and Reliability Test}

The result of validity test shows that all values of $r_{\text {count }}$ are more than $r_{\text {table }}(0,1966)$ at $5 \%$ significance level. It means that all questions are correlated with the total scores, and the data collected are valid then ready to be analyzed. While reliability test results are presented in Table. 5 which shows that all questions are confirmed reliable because the Cronbach Alpha value is higher than >0.6.

Table 5. Result of Questionnaire's Reliability Test

\begin{tabular}{lcc}
\hline \multicolumn{1}{c}{ Variables } & Cronbach Alpha & Explanation \\
\hline Self-Efficacy & 0,828 & Reliable \\
Motivation in Interest Aspect (MI) & 0,864 & Reliable \\
Motivation in Dedication Aspect (MD) & 0,888 & Reliable \\
Motivation in Confidence Aspect (MC) & 0,857 & Reliable \\
\hline
\end{tabular}

Source: Processed Data, 2017

\subsection{Regression Analysis}

\subsubsection{Regression Analysis on The Influence of Self-Efficacy toward Motivation in Interest Aspect}

The result of regression analysis in the form of regression coefficient value of 0.486 means that each $1 \%$ addition of Self-Efficacy level (X), then motivation in interest aspect (Y1) will increase by 0.486 . Therefore, the value of regression coefficient is positive (+), it can be said that Self-Efficacy has a positive effect on the motivation in interest aspect (Y1). This positive relationship means that Self-Efficacy and Motivation in the interest aspect has the same direction relationship. In other words, the higher the level of self-efficacy in student attitude the higher the motivation of students in the interest aspect to read English academic text.

Table 6. Regression Analysis on the Influence of Self-Efficacy toward Motivation in Interest Aspect

\begin{tabular}{lllcc}
\hline \multicolumn{1}{c}{ Model } & \multicolumn{1}{c}{$\begin{array}{c}\text { Regression } \\
\text { Coefficient }\end{array}$} & \multicolumn{1}{c}{$\begin{array}{c}\text { Standard of } \\
\text { Error }\end{array}$} & $\mathrm{T}_{\text {count }}$ & $\begin{array}{c}\text { Sicnificancy } \\
\text { Value }\end{array}$ \\
\hline Contants & 10,482 & 3,116 & 3,364 & 0,001 \\
Self-Efficacy & 0,486 & 0,116 & 4,188 & 0,000 \\
$\mathrm{~F}_{\text {count }}$ & & \multicolumn{3}{c}{17,542} \\
$\mathrm{R}^{2}$ & & 0,152 & \\
\hline
\end{tabular}

Source: Processed Data, 2017

\subsubsection{Regression Analysis on the Influence of Self-Efficacy toward Motivation in Dedication Aspect}

The value of regression coefficient of 0.628 means that every $1 \%$ addition of Self-Efficacy level $(\mathrm{X})$, the motivation in Dedication Aspect (Y2) will increase by 0.628 because the value of regression coefficient is positive (+), it can be said that Self-Efficacy has positive effect on Motivation to read English 
Academic text in Dedication Aspect (Y2). Within the positive relationship, Self-Efficacy and motivation in dedication aspects have a direct relationship. The higher level of Self-Efficacy in a student the higher the students' motivation to read English academic text in dedication aspect.

Table 7. Analysis on the Influence of Self-Efficacy toward Motivation in Dedication Aspect

\begin{tabular}{lllcc}
\hline Model & $\begin{array}{l}\text { Regression } \\
\text { Coefficient }\end{array}$ & Standar of Error & $\mathrm{T}_{\text {count }}$ & $\begin{array}{c}\text { Significansy } \\
\text { Value }\end{array}$ \\
\hline Constant & 10,741 & 2,882 & 3,727 & 0,000 \\
Self-Efficacy & 0,628 & 0,107 & 5,854 & 0,000 \\
$\mathrm{~F}_{\text {count }}$ & & \multicolumn{3}{c}{34,275} \\
$\mathrm{R}^{2}$ & & 0,259 & \\
\hline
\end{tabular}

Source: Processed Data, 2017

3.3.3. Regression Analysis on the Influence of Self-Efficacy toward Motivation in Confidence Aspect

The value of the regression coefficient of 0,529 means that every $1 \%$ addition of Self-Efficacy level (X), the motivation in Self-Confidence aspect (Y3) will increase by 0.529 because the value of regression coefficient is positive (+), it can be said that Self-Efficacy has positive effect on motivation in SelfConfidence aspect (Y3). Thus, Self-Efficacy and Motivation in Self-Confidence aspect has a one-way relationship. The higher level of Self-Efficacy the higher the motivation to read English text in Confidence aspect.

Tabel 8. Regression Analysis on the Influence of Self-Efficacy toward Motivation in Confidence Aspect

\begin{tabular}{ccccc}
\hline Model & $\begin{array}{c}\text { Koefisien } \\
\text { Regresi }\end{array}$ & Standar Error & $t_{\text {hitung }}$ & $\begin{array}{c}\text { Nilai } \\
\text { Signifikansi }\end{array}$ \\
\hline Constant & 9,898 & 2,935 & 3,373 & 0,001 \\
Self-Efficacy & 0,529 & 0,109 & 4,844 & 0,000 \\
F $_{\text {count }}$ & & \multicolumn{2}{c}{23,466} \\
$\mathrm{R}^{2}$ & \multicolumn{2}{c}{0,193} \\
\hline
\end{tabular}

Source: Processed Data, 2017

\subsection{Coefficient of Determination $\left(\mathbf{R}^{2}\right)$}

\subsubsection{Coefficient of Determination on the influence of Self-Efficacy toward motivation to read} English text in Interest Aspect

Table 9 shows the amount of $\mathrm{R}$ Square $=0.152$. Thus, the coefficient of determination can be determined through the formula $=0.152 \times 100 \%=15.2 \%$. So we can know that independent variable of Self-Efficacy could influence motivation to read English text in Interest Aspect up to 15,2\%. The rest, 100\% $-15.2 \%=84.8 \%$ is determined by other variables that are not studied in this study.

Table 9. Analysis on Coefficient of Determination on the Influence of Self-Efficacy toward Motivation to Read English Text in Interest Aspect

\begin{tabular}{ccccc}
\hline Model & $\mathrm{R}$ & $\mathrm{R}$ Square & Adjusted R Square & $\begin{array}{c}\text { Std. Error of the } \\
\text { Estimate }\end{array}$ \\
\hline 1 &, $390^{\mathrm{a}}$ &, 152 &, 143 & 4,432 \\
\hline
\end{tabular}

a. Predictors: (Constant), X (Self-Efficacy)

Source: Processed Primary Data, 2017

\subsubsection{Coefficient of Determination on the influence of Self-Efficacy toward motivation to read} English text in Dedication Aspect

Table 10 shows the amount of $\mathrm{R}$ Square $=0.259$. Thus, the coefficient of determination can be determined through the formula $=0.259 \times 100 \%=25,9 \%$. So we can know that independent variable of Self-Efficacy could influence motivation to read English text in dedication Aspect up to 25, 9\%. The rest, $100 \%-25,9 \%=74,1 \%$ is determined by other variables that are not studied in this study. 
Table 10. Analysis on Coefficient of Determination on the Influence of Self-Efficacy toward Motivation to Read English Text in Dedication Aspect

\begin{tabular}{ccccc}
\hline Model & $\mathrm{R}$ & R Square & Adjusted R Square & $\begin{array}{c}\text { Std. Error of the } \\
\text { Estimate }\end{array}$ \\
\hline 1 &, $509^{\mathrm{a}}$ &, 259 &, 252 & 4,099 \\
\hline
\end{tabular}

a. Predictors: (Constant), X (Self-Efficacy)

Source: Processed Primary Data, 2017

\subsubsection{Coefficient of Determination on the influence of Self-Efficacy toward motivation to read} English text in Self-Confidence Aspect

Table 11 shows the amount of $\mathrm{R}$ Square $=0.193$. Thus, the coefficient of determination can be determined through the formula $=0.193 \times 100 \%=19,3 \%$. So, we can know that independent variable of Self-Efficacy could influence motivation to read English text in dedication aspect up to 19, 3\%. The rest, $100 \%-19,3 \%=80,7 \%$ is determined by other variables that are not studied in this study.

Table 11. Analysis on Coefficient of Determination on the Influence of Self-Efficacy toward Motivation to Read English Text in Self-Confidence Aspect

\begin{tabular}{|c|c|c|c|c|}
\hline Model & $\mathrm{R}$ & R Square & Adjusted R Square & $\begin{array}{l}\text { Std. Error of the } \\
\text { Estimate }\end{array}$ \\
\hline 1 &, $440^{\mathrm{a}}$ &, 193 & , 185 & 4,175 \\
\hline
\end{tabular}

Source:Processed Primary Data, 2017

\subsection{Hypothesis Test}

\subsubsection{T-Test of Self-Efficacy Variable and Motivation to Read English Text in Interest Aspect}

Based on table 12, we know that the value of $t_{\text {count }}=4.188>1.664=t_{\text {table. }}$. It means that $\mathrm{H} 0$ is refused, which means that Self-Efficacy has a significant positive influence on students' motivation to read English text in interest aspect. Thus, Hypothesis 1 states that "there is a significant positive influence of SelfEfficacy on the motivation to read English text in the Interest Aspect" is (provable).

Tabel 12. T-Test of Self-Efficacy Variable and Motivation to Read English Text in Interest Aspect

\begin{tabular}{lllr} 
Model & & $\mathrm{t}$ & Sig. \\
\hline 1 & (Constant) & 3,364 &, 001 \\
& X (Self- Efficacy) & 4,188 &, 000 \\
a. Dependent Variable: Y1 (Interest) & & \\
\hline
\end{tabular}

Source: Processed Primary Data, 2017

\subsubsection{T-Test of Self-Efficacy Variable and Motivation to Read English Text in Dedication Aspect}

Based on table 13, we know that the value of $\mathrm{t}_{\text {count }}=5.854>1.664=\mathrm{t}_{\text {table. }}$ It means that $\mathrm{H} 0$ is refused, which means that Self-Efficacy has a significant positive influence on students' motivation to read English text in dedication aspect. Thus, Hypothesis 2 states that "there is a significant positive influence of SelfEfficacy on the motivation to read English text in the Dedication Aspect" is (provable). 
Tabel 13. $\mathrm{t}$ test of Self-Efficacy variable and Motivation to Read English Text in Dedication Aspect

\begin{tabular}{llrr} 
Model & \multicolumn{2}{c}{ Sig. } \\
\hline 1 & (Constant) & 3,727 &, 000 \\
& X (Self- Efficacy) & 5,854 &, 000 \\
\hline \multicolumn{2}{l}{ a. Dependent Variable: Y1 (Dedication) } \\
\hline
\end{tabular}

Source: Processed Primary Data, 2017

\subsubsection{T-Test of Self-Efficacy Variable and Motivation to Read English Text in Self-Confidence Aspect}

Based on table 14, we know that the value of $\mathrm{t}_{\text {count }}=4,844>1.664=\mathrm{t}_{\text {table. }}$. It means that $\mathrm{H} 0$ is refused, which means that Self-Efficacy has a significant positive influence on students' motivation to read English text in self-confidence aspect. Thus, Hypothesis 3 states that "there is a significant positive influence of Self-Efficacy on the motivation to read English text in the self-confidence Aspect" is (provable).

Tabel 14. $t$ test of Self-Efficacy variable and Motivation to Read English Text in SelfConfidence Aspect

\begin{tabular}{llrr}
\multicolumn{2}{c}{ Model } & $\mathrm{t}$ & Sig. \\
\hline 1 & (Constant) & 3,373 &, 001 \\
& X (Self- Efficacy) & 4,844 &, 000 \\
a. Dependent Variable: Y1 (Self-Confidence) & & \\
\hline
\end{tabular}

Source: Processed Primary Data, 2017

\subsection{Discussion}

The results of the study have shown that Self-Efficacy significantly affects on one of the motivation aspects to read English academic text. That is someone interest to read. It means, the higher self-efficacy perceived by a student, that he or she is capable of doing, the stronger student's interest to read English academic text. The relationship between both variables is very clear because reading English academic text is a challenging task for English as a foreign language (TEFL) student. In a slightly different context, this result is in line with the findings of (Zulianto, Santoso, \& Sawiji, 2013) which concluded that there is a significant influence of Self-Efficacy on one's interest, especially in entrepreneurship of college students. This finding is also in line with the previous facts that students' self-perception about their ability has significant influence to raise their interest to read English materials. The result of this study exposed the significant sources of one's interest in and excitement about reading was sparked by the individual understanding of themselves. As Strategic Marketing and Research Inc. (2013) reported various sources of motivation including family members (especially mother), teacher, and themselves.

In addition, the hypothesis proof indicated that Self-Efficacy has a significant positive influence on the motivation of reading English academic text in the aspect of dedication. In this case, dedication is understood as the dimension of one's engagement to an activity. It means, to increase person's level of dedication in devoting his time and thought to read can be done by supporting students' perceives on their Self-Efficacy. This confirmation supports the research conclusion of (Mesurado, Richaud, \& Mateo, 2015) which attests to the significant influence of Self-efficacy on one's dedication as one dimension of learning engagement. As an intrinsic motivation, dedication is desirable since it will energize students to gain success. Sometime, students must accomplish assignments that are not desirable to them. In the reading class context, there are books that are not interesting for some students, however, it is a necessary assignment. In this situation, the motivation that enables students to put effort effectively is called dedication (Cambria \& Guthrie, 2010). Therefore, students' reason to read undesirable reading materials is their belief that they can do that believe that reading this material is important. Every student owns potential dedication. For certain students, to develop reading skill will be hard. However, according to this research finding, dedication is effected by personal self-efficacy that related to their will to do something. 
The results also indicated a significant positive influence of Self-Efficacy on other aspects of motivation to read English academic text, self-confidence. This result can be understood that one's confidence to raise the level of English reading materials will be influenced by how high the level of selfefficacy felt by the individual. In other words, if person's Self-efficacy is pretty high then he will be more confident to access English reading with increasingly difficult levels. These findings prove the view of (Cambria \& Guthrie, 2010) who said that self-confidence has a closer relationship to achievement than any other motivation that exists in any school. This is due to self-confidence, which refers to belief in selfcapacity, is close to success. It is further said that students who begin to doubt their ability will likely be low in English skills; even in speaking, writing, or reading skill. Thus, the teacher has an important role to develop a conducive interaction to grow students' self-efficacy, thereby will generate their self-confidence in reading English texts.

\section{CONCLUSION}

This research resulted in the finding the Self-efficacy (SE) has a positive and significant influence on the motivation of reading English academic texts in the aspect of interest (MI), dedication aspect (MD), and aspects of self-confidence (MC). It means, the Increasing of Self-Efficacy (SE) perceived by students will encourage individual's interest to read English texts. Thus, the result of this study shows that the whole hypotheses of this study are accepted.

By proving the hypothesis of this study, an English teacher, especially a reading class, should have an attention in several aspects other than teaching materials. In order to support students' achievement in language classes, a teacher must play a role as a motivator. In addition, the teachers have to effort on how to develop students' self-efficacy in doing their task. Thus, the students will have more interest, dedication, and confidence in learning English.

This finding has limitations on the scope that is still narrow. Many researchers have argued about the broader dimensions of motivation for further research. In addition, the coverage of respondents in this study also has not generalized the existing population, explicitly students of higher education. This is because the population of the university student is still very broad and heterogeneous. Therefore, further research is needed with broader and more heterogeneous characteristics of respondents.

\section{REFERENCES}

Bandura, A. (1997). Self-efficacy: The exercise of control. New York: W. H. Freeman and Company.

Cambria, J., \& Guthrie, J. (2010). Motivating and engaging students in reading. New England Reading Association Journal, 46(1), 16-29.

Karen D. Wood, Anne Tope Edwards, \& Patricia Hill-Miller. (2006). Research into Practice: Motivation, Self-Efficacy, and the Engaged Reader. Middle School Journal, 37(5), 55-61.

Kevin. (2018). English Teaching in Indonesia is too Rigid. Retrieved January 25, 2017, from http://www.tribunnews.com/australia-plus/2014/05/30/pengajaran-bahasa-inggris-di-indonesiaterlalu-kaku

Margolis, H., \& McCabe, P. P. (2003). Self-Efficacy: A Key to Improving the Motivation of Struggling Learners. Preventing School Failure: Alternative Education for Children and Youth, 47(4), 162-169. http://doi.org/10.1080/10459880309603362

McCabe, P. (2003). Enhancing self-efficacy for high-stakes reading tests. The Reading Teacher, 57(1), 1220.

Mesurado, B., Richaud, M. C., \& Mateo, N. J. (2015). Engagement, flow, self-efficacy, and Eustress of University Students: a cross-national comparison between the Philippines and Argentina. Journal of Psychology, 0(0), 1-24.

Schunk, D. H. (2003). Self-efficacy for reading and writing: Influence of modeling, goal setting, and selfevaluation. Reading and Writing Quarterly, 19, 159-172.

Snow, C., Burns, M., \& Griffin, P. (1998). Preventing Reading Difficulties in Young Children. Washington: National Academy Press. 
Strategic Marketing and Research Inc. (2013). Factors Affecting Reading Ability in School Age Children. Journal of Educational Research, 73, 1-41.

Zulianto, M., Santoso, S., \& Sawiji, H. (2013). Effect of Self-Efficacy and Entrepreneurship Education on Entrepreneurship Interest of University Students of Trade Faculty of Economics Education of State University of Malang. Jurnal Pendidikan Insan Mandiri, l(1). 